\section{Efficacy of Ketoprofen With or Without Omeprazole for Pain And Inflammation Control After Third Molar Removal}

Luis Fernando Simoneti ${ }^{1}$, Giovana Maria Weckwerth ${ }^{1}$, Thiago José Dionísio', Elza Araujo Torres' ${ }^{1}$ Paulo Zupelari-Gonçalves ${ }^{1}$, Adriana Maria Calvo ${ }^{1}$, José Roberto Lauris², Flávio Cardoso Faria', Carlos Ferreira Santos ${ }^{1}$

In view of the gastrointestinal problems generated by the ketoprofen use, the ketoprofen association with omeprazole is available on the market. However, this association efficacy in acute pain control has not been established. Bilateral extraction of lower third molars in similar positions is currently the most used model for the evaluation and investigation of the efficacy and pharmacological effects of new compounds for the treatment of acute postoperative pain. The randomized and crossover study consisted in evaluating the clinical efficacy of therapy performed by ketoprofen $100 \mathrm{mg}$ (twice daily-b.i.d.) versus ketoprofen $200 \mathrm{mg}+$ omeprazole $20 \mathrm{mg}$ (once daily-q.d.) to pain, swelling and trismus control in the bilateral extraction model of lower third molars in similar positions in two different appointments, in 50 volunteers. Volunteers reported significantly less postoperative pain at various post-operative periods and consumed less rescue analgesic medication (acetaminophen $750 \mathrm{mg}$ ) throughout the study when they took the combination of ketoprofen $200 \mathrm{mg}+$ omeprazole $20 \mathrm{mg}$ (q.d.). Following administration of both study drugs, no gastrointestinal adverse reactions were reported by volunteers. Furthermore, the evaluations of the drugs in pain control by the volunteers were significantly favorable to ketoprofen $200 \mathrm{mg}+$ omeprazole $20 \mathrm{mg}$ (q.d.). For swelling and trismus control, the treatments presented similar results. In conclusion, when volunteers took ketoprofen $200 \mathrm{mg}+$ omeprazole $20 \mathrm{mg}$ (q.d.), they reported significantly less postoperative pain at various post-surgical periods and consumed less rescue analgesic medication throughout the study compared with ketoprofen $100 \mathrm{mg}$ (b.i.d).

\author{
'Department of Biological \\ Sciences, Bauru School of \\ Dentistry, USP - Universidade de \\ São Paulo, Bauru, SP, Brazil \\ ${ }^{2}$ Department of Pediatric Dentistry, \\ Orthodontics and Community \\ Health, Bauru School of Dentistry, \\ USP - Universidade de São \\ Paulo, Bauru, SP, Brazil
}

Correspondence: Carlos F. Santos, Alameda Octávio Pinheiro Brisolla, 975, 17012-901. Bauru, SP, Brazil. Phone/Fax: +55 1432358295 . e-mail: cfsantos@fob.usp.br

Keywords: ketoprofen, omeprazole, pain control, lower third molar surgery.

\section{Introduction}

Bilateral extraction of lower third molars in similar positions is currently the most used model for the evaluation and investigation of the efficacy and pharmacological effects of new compounds for the treatment of postoperative pain, such as analgesics and anti-inflammatory drugs $(1,2)$. This type of surgical procedure is recommended since some tissues are manipulated and traumatized in the region where the extraction is performed, composed mainly of loose connective tissue that contains blood and lymphatic vessels. Due to their manipulation, a number of functional and structural changes are expected; among them are the release of exudate and the formation of swelling, with subsequent onset of trismus and pain (3-5).

Pain resulting from the extraction of third molars is usually short in duration and of moderate intensity, with greater pain intensity soon after the surgical procedure (6). Swelling is formed due to tissue manipulation during surgery, and presents maximum intensity after $48 \mathrm{~h}$ of the surgical procedure (7). Trismus after third molar extraction is closely related to the level of swelling and inflammation generated by the surgery, ie, the greater the level of swelling resulting from an inflammatory response, the greater degree of limitation of mouth opening is expected.

To prevent the occurrence of postoperative complications, such as acute pain, studies indicate the use of physical procedures, such as the use of cold packs soon after the surgeries. In addition to these procedures, non-steroidal anti-inflammatory drugs (NSAIDs) have been extensively used as adjuvants for the reduction of these postoperative complications derived from the extractions of the lower third molars $(1,2,8,9)$.

Scientific evidence demonstrates that NSAIDs exhibit their therapeutic effect by inhibiting cyclooxygenase (COX), and this inhibits the production of prostaglandins (PGs) and thromboxanes. According to the literature, PGs alone do not cause pain, but they potentiate the action of chemical mediators of inflammation, such as bradykinin on the nociceptive fibers, which consequently cause pain amplification (10). COX is known in two isoforms: COX-1, and COX-2. A third isoform of this enzyme family, known as COX-3 has been discovered, which unlike COX-1 and COX2 , would not produce proinflammatory prostanoids, but rather anti-inflammatory substances. COX-1 is known as a constitutive enzyme. It is associated with the production of prostaglandins and results in several physiological effects, 
such as gastric protection, platelet aggregation, vascular homeostasis and maintenance of renal blood flow (11).

NSAIDs are commonly prescribed to combat a wide variety of inflammatory pain conditions such as osteoarthritis, rheumatic diseases, soft tissue trauma, and postoperative pain. NSAIDs are also commonly used in dental practice, such as in the treatment of orofacial pain or pain after surgical procedures such as dental extractions $(1,2,8,9)$. Ketoprofen is a non-steroidal anti-inflammatory drug, derived from arylcarboxylic acid, belonging to the propionic acid group of NSAIDs. Ketoprofen has antiinflammatory, antipyretic and peripheral and central analgesic activity. It inhibits the synthesis of prostaglandins and platelet aggregation, however, its mechanism of action is not completely elucidated $(10,12)$. Evidence from a number of clinical studies suggests that ketoprofen is an effective analgesic, with its therapeutic effect generally at doses ranging from 75 to $300 \mathrm{mg}$ per day (12). Omeprazole is a potent inhibitor of $\mathrm{H}^{+} / \mathrm{K}^{+}$ATPase (proton pump inhibitor), which is responsible for the secretion of hydrochloric acid by parietal gastric cells. Omeprazole was well established as a highly effective inhibitor of acid secretion. The drug has a long duration of action. Remaining acid secretion is significantly reduced at 21 days after withdrawal of omeprazole $20 \mathrm{mg} /$ day for 4 weeks in volunteers with duodenal ulcer. The effect of omeprazole on gastric acid secretion is dose-dependent $(13,14)$.

In the international literature, several NSAIDs have been studied in randomized, cross-over models, demonstrating their efficacy in the management of acute pain after bilateral extraction of lower third molars in similar positions $(1,2,8,9)$. This study model of bilateral removal of lower third molars with similar positions is unique, since the same surgery is essentially performed twice in the same patient, and will serve as its own control, thus avoiding response variations (10).

In view of the gastrointestinal problems generated by the use of ketoprofen, the association of ketoprofen with omeprazole is available on the market. However, the efficacy of this association in the acute control of pain has not been established. In the combination of ketoprofen $200 \mathrm{mg}+$ omeprazole $20 \mathrm{mg}$ the pharmacokinetic profiles of the ketoprofen and omeprazole components are comparable to those of the separately administered ketoprofen and omeprazole components, but the formulation has a sustained release form of ketoprofen and a gastroresistant release form of omeprazole, both suitable for once-daily therapeutic dosing. There is no influence on the pharmacokinetics of ketoprofen when administered concomitantly with omeprazole, and vice versa (15). Therefore, the objective of the present study was to evaluate the clinical efficacy of ketoprofen 100 mg tablets (b.i.d.) versus ketoprofen $200 \mathrm{mg}+$ omeprazole $20 \mathrm{mg}$ (q.d.), both administered enterally for the control of pain, swelling and trismus in the bilateral extraction model of lower third molars with similar positions in two different appointments.

\section{Material and Methods}

The present randomized and cross-over study was performed in volunteers regularly enrolled at the Bauru School of Dentistry, University of São Paulo, after approval by the Institutional Review Board (CAAE: 44808215.6.0000.5417) in accordance with the Declaration of Helsinki for Human Research. The clinical trial was registered under ID \# NCT02730026 at ClinicalTrials.gov. The present study included healthy individuals (ASA I according to the classification of the American Society of Anesthesiologists) of both sexes, aged 18-38 years, with indication of bilateral third molar extraction.

Volunteers could not have inflammations or infections prior to surgical procedures, such as pericoronitis, alveolitis, osteonecrosis or mucositis. In addition, the volunteers signed the Informed Consent Form. In order to standardize the sample, the volunteers should present the positions of the lower third molars, roots and similar degree of impaction on the right and left sides of the mouth according to the classification of Pell and Gregory as well as Winter (16), which was confirmed by orthopantomographic radiography and clinical examination.

Eligibility criteria included adults without inflammation, infection and systemic diseases that could possibly interfere with the study. Exclusion criteria were as follows: any history of allergy, gastrointestinal bleeding/ulcers, kidney disease, asthma or any known allergic sensitivity to ketoprofen, omeprazole or any NSAID. Pregnant or lactating women were also excluded from the study, as well as volunteers who used antidepressants, diuretics or NSAIDs 7 days prior to the start of the experiments $(1,2,8,9)$.

All lower third molars extractions were performed with the same technique and with the same magnitude of surgical trauma, all third molars were impacted, with necessity of bone removal on both opposing sides of the mandible in each of the volunteers of the research. All surgeries were performed by the same oral \& maxillofacial surgeon (L.F.S.) and assisted by the same assistant in two different appoints, being performed in two visits with intervals of one to two months. The choice of the side to be operated on and the NSAID to be used [ketoprofen $100 \mathrm{mg}$ twice daily (b.i.d.) (Profenid ${ }^{\oplus}$, Sanofi-Aventis Farmacêutica Ltda, Suzano/SP, Brazil) or ketoprofen 200 mg + omeprazole 20 mg once daily (q.d.) (Profenid Protect ${ }^{\circledR}$, Sanofi-Aventis Farmacêutica Ltda, Suzano/SP, Brazil), each hard gelatin capsule contains $200 \mathrm{mg}$ of ketoprofen (extended-release 
microgranules) and $20 \mathrm{mg}$ of omeprazole (gastroresistant microgranules) for 4 days] was done in a randomized manner using a randomization worksheet obtained through the program available at: http://www.randomization.com, number 19482.

The randomization determined which side would be operated and the drug to be prescribed in the first surgery. Therefore, in the second surgery the opposite side would be operated and the other drug prescribed. The drugs were coded in even and odd numbers and the only person responsible for prescribing the postoperative medication knew which drug was being prescribed. This information was not disclosed to researchers until the end of the study.

All anesthetic procedures were performed with blockade of the buccal, lingual and inferior alveolar nerves, initially administering a cartridge $(1.8 \mathrm{~mL})$ of local anesthetic. After anesthesia of the lower lip, half a cartridge $(0.9 \mathrm{~mL})$ of another tube not yet used and of the same anesthetic solution was administered by an infiltrative terminal technique to diminish hemorrhage and guarantee mucosal anesthesia. The local anesthetic used was 4\% articaine with 1:200,000 epinephrine, according to our laboratory studies $(2,8,9,17,18)$.

that the analgesia produced by the anti-inflammatory drug provided was insufficient, acetaminophen (EMS S/A, Hortolândia/SP, Brazil) was prescribed at $750 \mathrm{mg}$ every $8 \mathrm{~h}$

(2,8,9,17-20). Throughout the surgical procedure, notations were made such as: the amount of anesthetic administered, the hemodynamic data of the volunteer at each surgical stage through the DX 2021 Dixtal device (Biomédica Ind e Com Ltda, Marilia/SP, Brazil), the amount of bleeding and the degree of difficulty of each stage of surgery (incision, flap, osteotomy, tooth section, extraction, cleaning and suturing) $(1,2,8,9,17-19,21)$.

As soon as the procedure was finished, the volunteer immediately received the first anti-inflammatory tablet according to the randomization (ketoprofen $100 \mathrm{mg}$ b.i.d. or ketoprofen $200 \mathrm{mg}+$ omeprazole $20 \mathrm{mg}$ q.d.) and received a pain chart, in which he noted the exact times he took his medication, according to the time of the end of the surgery. In this pain chart, the volunteer was instructed to report any gastrointestinal adverse reaction, fill out if there was a need for ingestion of the rescue medication (acetaminophen $750 \mathrm{mg}$ ), and the volunteer was instructed to complete a Visual Analog Scale (0 to $100 \mathrm{~mm}$ ) for postoperative pain, which contained "no pain $(0 \mathrm{~mm})$ " and "worst pain possible $(100 \mathrm{~mm})$ ). No antibiotics were prescribed to the volunteers due to the pharmacological protocol applied in the present research, which corroborates previous studies by out group (22).

The parameters evaluated were as follows (Table 1):
- Subjective evaluation of postoperative pain, which was recorded by the volunteer himself on a Visual Analog Scale (0 to $100 \mathrm{~mm}$ ). Subjective pain assessments were performed by volunteers at the following times after administration of the drugs $[0 ; 15 ; 30$ and $45 \min , 1 ; 1.5 ; 2 ; 3 ; 4 ; 5 ; 6 ; 7 ; 8$; $10 ; 12 ; 16 ; 24,48,72$ and $96 \mathrm{~h}]$;

- Mouth opening (distance in $\mathrm{mm}$ between the edges of the upper and lower incisors during the maximum opening achieved by the volunteer) before the surgery, on the 2nd postoperative day and at the time of sutures removal (7th day, respectively). The postoperative ability to open the mouth was expressed as a percentage of the preoperative measurement;

- Onset and duration of surgery after anesthetic administration;

- Patients were asked if they experienced any discomfort and/or side effects at the time of appointment for suture removal;

- Total amount of pain relief medication used (acetaminophen $750 \mathrm{mg}$ );

- Measurement of facial swelling on the 2nd postoperative day and on the 7th postoperative day (removal of stitches) and quality of healing.

\section{Statistical Analysis}

$\mathrm{G}^{*}$ Power software v.3.0.10 was used for the sample calculation. Data were tabulated using Microsoft ${ }^{\circledR}$ Excel 2012 (version 10.6871.6870) and GraphPad Prism (version 4.0) was used to perform statistical analysis. For comparison of some parameters proposed in the study the paired t test for the parametric data and the Wilcoxon test for nonparametric data were used. For the analysis of pain data, Friedman test was used because the data are not parametric. For the mouth opening and trismus analyzes the two-way ANOVA was used since the data are parametric. Mean \pm standard deviations were used to express the parametric data. Median [interquartile ranges] were used to express the non-parametric data. The level of significance adopted was $5 \%$.

The sample size calculation was performed based on mouth opening, trismus, amount of rescue medication and pain $8 \mathrm{~h}$ after the surgery (peak) data from previously studies $(8,9)$. The minimal effect size was 0.37741 , the power was $70 \%$ and the significance level was $5 \%$.

\section{Results}

After the eligibility evaluation, the study consisted of 54 volunteers; of these, two volunteers evolved with purulent discharge in the postoperative period, one patient became pregnant in the research development and one patient 
had different duration of both surgeries, therefore these 4 volunteers they were excluded from the study with the total sample composed of 50 volunteers. There were 33 women (66\%) and 17 men (34\%) aged 18-38 years (mean age $24 \pm 5$ years) (CONSORT flow chart, Fig. 1).

Each of the 50 volunteers completing this study had each of the lower third molars classified as IA $(n=24)$, IB $(n=3), \| A(n=12), I I B(n=9)$ and IIC $(n=2)$ according to Pell and Gregory; and vertical $(n=27)$, horizontal $(n=$ 17) and distal $(n=6)$ according to Winter (16). The need for osteotomy or tooth sectioning was determined by $x$-ray analysis confirmed by visual inspection during the surgery. When volunteers took ketoprofen $100 \mathrm{mg}$ b.i.d., osteotomies and tooth sectioning were performed in 32 surgeries, 9 surgeries only osteotomy, and osteotomies and tooth sectioning were not necessary in 9 surgeries. When volunteers took ketoprofen $200 \mathrm{mg}+$ omeprazole $20 \mathrm{mg}$ q.d., osteotomies and tooth sectioning were performed in 30 surgeries, only osteotomies in 12 surgeries, and 9 did not require osteotomies and tooth sectioning. For all these results, no significant statistical difference was found regarding surgical trauma (Table 2).

The mean duration of surgery when volunteers received ketoprofen $100 \mathrm{mg}$ b.i.d. was $19.3 \pm 5.8 \mathrm{~min}$, and ketoprofen $200 \mathrm{mg}+$ omeprazole $20 \mathrm{mg}$ q.d. was $21 \pm 7.7$, without a statistically significant difference $(p=0.0768$, Table 3$)$. In the postoperative pain scores documented by each volunteer there was a statistically significant difference in the periods of $1.5,7,8,10,12,16,24,48$ and $72 \mathrm{~h}$ postoperative ketoprofen $100 \mathrm{mg}$ b.i.d. and ketoprofen 200 mg + omeprazole 20 mg q.d. (p<0.05) (Fig. 2).

After standard administration of the study drugs in both groups, the mean amount of rescue analgesic medication taken per volunteer was 3 [4.5] tablets of $750 \mathrm{mg}$ acetaminophen per person in the ketoprofen 100 $\mathrm{mg}$ b.i.d. group of and 0.5 [3] in the ketoprofen $200 \mathrm{mg}$ + omeprazole $20 \mathrm{mg}$ q.d. during the entire postoperative period of the study $(p=0.0026)$. However, the time to use the first pain relief medication and the level of pain reported in both groups were similar ( $p>0.05$ ) (Table 4).

When analyzed for swelling and trismus values, there was no statistically significant difference in the sum of the mean linear distances between the two drugs studied ( $p>0.05$ ). The swelling had its maximum peak significantly increased during the second day, and did not return to baseline after the seventh day for both treatments $(p<0.05)$.

Table 1: Parameters evaluated in the study

\begin{tabular}{|c|c|}
\hline Parameter & Unit \\
\hline Quality of anesthesia & $\begin{array}{l}\text { 3-point scale: 1) no discomfort during surgery; } 2 \text { ) any discomfort without the need } \\
\text { for additional anesthesia; 3) any discomfort with the need for additional anesthesia }\end{array}$ \\
\hline Overall experience of surgery reported by patient & 5-point scale: 1) “poor”; 2) “fair”; 3) “good”; 4) “very good”; 5) “excellent” \\
\hline Body temperature & Preoperative period, $2^{\text {nd }}, 7^{\text {th }}$ postoperative day $\left({ }^{\circ} \mathrm{C}\right)$ \\
\hline Total volume of local anesthetic & $\mathrm{mL}$ \\
\hline Onset of anesthetic agent action & Min \\
\hline $\begin{array}{l}\text { Total amount of rescue medication } \\
\text { (750 mg acetaminophen) }\end{array}$ & Number of tablets \\
\hline $\begin{array}{l}\text { Systolic, diastolic, and mean arterial pressure; } \\
\text { heart rate and oxygen saturation* }\end{array}$ & $\mathrm{mmHg} ; \mathrm{bpm}$ and $\% \mathrm{SpO}_{2}$ \\
\hline Intraoperative bleeding & 3-point scale: 1) minimal bleeding; 2) normal bleeding; 3) excessive bleeding \\
\hline Surgery difficulty & $\begin{array}{l}\text { 3-point scale: 1) no need for osteotomies without tooth } \\
\text { sectioning; 2) need for osteotomies without tooth sectioning; } \\
\text { 3) need for osteotomies and tooth sectioning complicated }\end{array}$ \\
\hline Subjective evaluation of postoperative pain & Visual analog scale (VAS, 0 to $100 \mathrm{~mm}$ ) \\
\hline Mouth opening & Preoperative period, $2^{\text {nd }}, 7^{\text {th }}$ postoperative day $(\mathrm{mm})$ \\
\hline Surgery duration & $\min$ \\
\hline Adverse reactions & $\begin{array}{l}\text { Observed by the surgeon or reported by the volunteer, during the surgery in } \\
\text { the first postoperative hour and during the } 2^{\text {nd }} \text { and } 7^{\text {th }} \text { days after surgery. }\end{array}$ \\
\hline Facial swelling & Preoperative period, $2^{\text {nd }}, 7^{\text {th }}$ postoperative day $(\mathrm{mm})$ \\
\hline Quality of wound healing & $\begin{array}{l}7^{\text {th }} \text { day; 3-point scale: 1) normal healing without inflammation; } \\
\text { 2) delayed healing; 3) healing complicated by inflammation } \\
\text { or local infection with or without purulent material }\end{array}$ \\
\hline
\end{tabular}

* Dixtal ${ }^{\circledR}$ (model DX2021, DixtalBiomédicaInd and Com Ltda, Marília, SP, ANVISA/MS 10293490035, model number 101503732). 
Regarding the maximum mouth opening, there was a statistically significant difference $(p<0.05)$ between the preoperative (basal) and postoperative periods ( $48 \mathrm{~h}$ and 7 days) for both treatments. On the other hand, there was no significant difference when compared to the study drugs ( $p>0.05)$. Another parameter evaluated and that did not present significant difference between the when volunteers took the drugs ketoprofen 100 mg b.i.d. vs ketoprofen 200 $\mathrm{mg}+$ omeprazole $20 \mathrm{mg}$ q.d. was the quality of healing.

Following administration of both study drugs, no gastrointestinal adverse reactions were reported by volunteers. In addition, no adverse reaction to the use of any

\section{Enrollment}

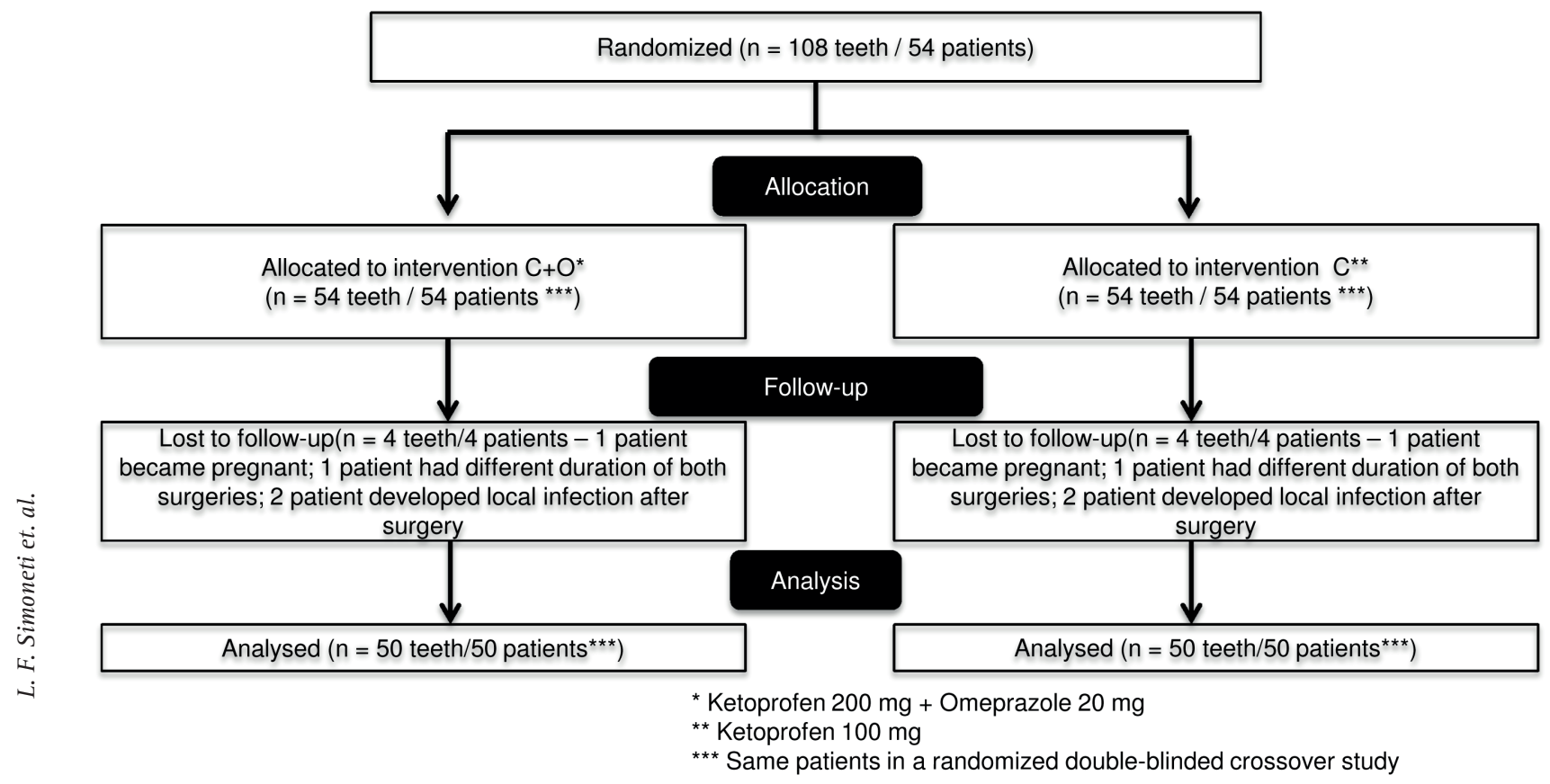

Figure 1: Study flowchart.

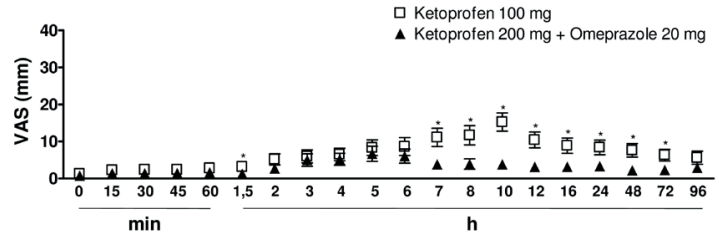

Figure 2. Visual analog scale (VAS) of self-reported postoperative pain scores after lower third molar surgeries assessed at 15, 30, 45 min and 1, 1.5, 2, 3, 4, 5, 6, 7, 8, 10, 12, 16, 24, 48, 72 and 96 h. Scores could range from 0 to $100 \mathrm{~mm}$ with larger scores indicating increased pain. Data are presented as median and interquartile range $(n=50) .{ }^{*}$ Indicates a p-value $\leq 0.05$, Wilcoxon test, for each assessed time period comparing ketoprofen $100 \mathrm{mg}$ b.i.d. and ketoprofen $200 \mathrm{mg}+$ omeprazole $20 \mathrm{mg}$ q.d.

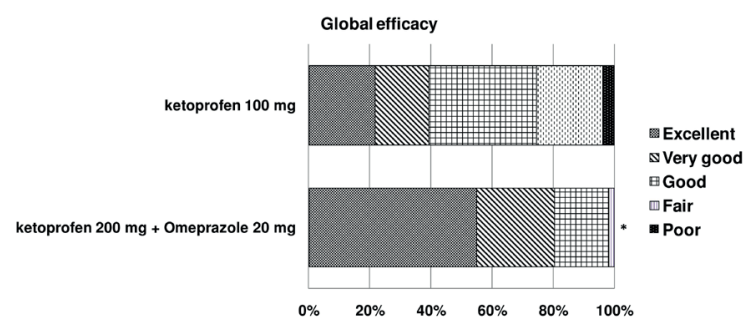

Figure 3. Self-reported global efficacy of oral ketoprofen $100 \mathrm{mg}$ b.i.d. and ketoprofen $200 \mathrm{mg}+$ omeprazole $20 \mathrm{mg}$ q.d. during the seventh postoperative day as assessed using a 5-level Likert scale $(\mathrm{n}=50)$. The format of the Likert ratings was "excellent," "very good," "good," "fair," or "poor". * Indicates a p-value $\leq 0.05$, Wilcoxon test for the "excellent" sub-group between research medications. 
anesthetic solution was observed by the surgeon or reported by the volunteers during and after the surgeries. There was also no statistically significant difference regarding the time of action of the local anesthetic 4\%articaine with 1:200,000 epinephrine, number of cartridges used in each extraction and quality of anesthesia. In addition, during all surgeries, no hypertensive peaks were observed in the systolic, diastolic and mean arterial pressure data. The oxygen saturation, heart rate and bleeding index did not change significantly during the surgeries (Table 3 ).

There were statistically significant differences observed between the global evaluations of volunteers for ketoprofen $100 \mathrm{mg}$ b.i.d. and ketoprofen $200 \mathrm{mg}+$ omeprazole $20 \mathrm{mg}$ q.d. According to the global postoperative evaluations of the volunteers, ketoprofen $200 \mathrm{mg}+$ omeprazole $20 \mathrm{mg}$ q.d. was classified as excellent and very good for postoperative pain, swelling and trismus control, significantly better evaluated when compared to ketoprofen $100 \mathrm{mg}$ b.i.d. (p $=0.0001$ ) (Fig. 3).

\section{Discussion}

The present randomized and cross-over study investigated the clinical efficacy of postoperative pain control, swelling, and trismus using enterally ketoprofen 100 $\mathrm{mg}$ once every $12 \mathrm{~h}$ and ketoprofen $200 \mathrm{mg}$ in combination with omeprazole $20 \mathrm{mg}$ administered once every $24 \mathrm{~h}$, after extractions of lower third molars under local anesthesia. As a method of evaluating acute postoperative pain, some researchers use analog visual scales, in which volunteers report the evaluation of the intensity of their pain $(1,2,8,9,23)$, as the present study, which used the visual analog scale to determine the intensity of postoperative

Table 2. Third molars position according to Pell \& Gregory and Winter, number of surgeries without osteotomy and tooth sectioning, number of surgeries with only osteotomy and number of surgeries with osteotomy and tooth sectioning.

\begin{tabular}{|c|c|c|}
\hline & Ketoprofen $100 \mathrm{mg}$ b.i.d. & Ketoprofen $200 \mathrm{mg}$ + Omeprazole $20 \mathrm{mg}$ q.d. \\
\hline IA & 24 & \\
\hline IB & 3 & \\
\hline IC & 0 & \\
\hline IIA & 12 & \\
\hline IIB & 9 & \\
\hline IIC & 2 & \\
\hline IIIA & 0 & \\
\hline IIIB & 0 & \\
\hline IIIC & 0 & \\
\hline Vertical & 27 & \\
\hline Horizontal & 17 & \\
\hline Distoangular & 6 & \\
\hline Mesioangular & 0 & \\
\hline Inverted & 0 & \\
\hline Buccal/Lingual Obliquity & 0 & \\
\hline Surgeries without osteotomy and tooth sectioning & 9 & 9 \\
\hline Surgeries with only osteotomy & 9 & 11 \\
\hline Surgeries with osteotomy and tooth sectioning & 32 & 30 \\
\hline
\end{tabular}

Pell and Gregory classification based on the amount of tooth covered by the anterior border of the ramus: Class I 3rd molar impaction: Situated anterior to the anterior border of the ramus, Class II 3rd molar impaction: Crown 1/2 covered by the anterior border of the ramus. Class III 3rd molar impaction: Crown fully covered by the anterior border of the ramus. The depth of the impaction relative to the adjacent tooth (A,B,or C). Class A: the occlusal plane of the impacted tooth is at the same level as the adjacent tooth. Class B: the occlusal plane of the impacted tooth is between the occlusal plane and the cervical line of the adjacent tooth. Class C: the occlusal plane of the impacted tooth is apical to the cervical line of the adjacent tooth. Winter classification: Mesio-Angular: The impacted tooth is tilted toward the 2nd molar in a mesial direction. DistoAngular: The long axis of the 3rd molar is angled distally / posteriorly away from the 2nd molar. Horizontal: The long axis of the 3rd molar is horizontal. Vertical: The long axis of the 3rd molar is parallel to the long axis of the 2nd molar. Buccal / Lingual Obliquity: In combination with the above, the tooth can be buccally (tilted towards the cheek) or lingually (tilted towards the tongue) impacted. Inverted: In this position, the tooth is displaced in an upside down position, with the crown facing the alveolar nerve. 
pain, ketoprofen $200 \mathrm{mg}+$ omeprazole $20 \mathrm{mg}$ q.d. had a superior analgesic effect when compared to ketoprofen 100 $\mathrm{mg}$ b.i.d., with a statistically significant difference in the control of pain, mainly in the periods of $1.5,7,8,10,12,16$, 24,48 and $72 \mathrm{~h}$ postoperative. It is worth emphasizing at this moment that the acute pain control after the surgeries by both drugs was effective, since the literature reports that pain below $45 \mathrm{~mm}$ does not affect the daily routine of the volunteers $(17,21,24)$.

The efficacy of ketoprofen $100 \mathrm{mg}$ has also been compared with methylprednisolone in pain control after third molar surgery, with peak pain intensity occurring within the first $12 \mathrm{~h}$ with the use of both drugs (12). Although there were significant differences in pain scores in the present study, the results showed that ketoprofen $100 \mathrm{mg}$ presented the highest pain intensity in the 10-hour postoperative period. However, it is worth noting that for both drugs evaluated, pain control was satisfactory since the volunteers reported less than $20 \mathrm{~mm}$ in the visual analog scale score, which reflects in mild pain according to Hawker et al. 2011 (23).

Pain, swelling and trismus arising from the extraction of lower third molars are usually influenced by some variables such as time of surgery, medication, postoperative care and tissue manipulation (7). Data from the present study revealed that the duration of surgery was the same when volunteers were medicated either with ketoprofen 200 mg + omeprazole $20 \mathrm{mg}$ q.d. or ketoprofen $100 \mathrm{mg}$ b.i.d., thus demonstrating the reliability of the experimental model used in the present study since the volunteers were submitted to the same magnitude of surgical trauma.

Swelling derived from third molar extractions presents maximum intensity after $48 \mathrm{~h}$ of the surgical procedure (7). In the present study, swelling had its peak during the second postoperative day as reported by the aforementioned study. After adding the linear measures of swelling and trismus of 48 $\mathrm{h}$ and 7 days postoperatively and comparing with the baseline measurement, the data demonstrated that there was no statistically significant difference between the medications, which shows that there was a standardization of surgical trauma in both, and that both ketoprofen $100 \mathrm{mg}$ b.i.d. and ketoprofen 200 mg + omeprazole $20 \mathrm{mg}$ q.d. were equalized in the control of postoperative swelling and trismus.

Another variable widely used to predict the difficulty of extracting the lower third molars, and influences the level of surgical trauma, is the Pell and Gregory (9) classification based on their spatial relationships with the ascending mandible branch and the occlusal plane (16). In the present study, 
although most of the lower third molars were classified as IA ( $\mathrm{n}=24)$ according to Pell and Gregory and in the vertical position $(n=27)$ according to Winter $(16)$, there was a high level of surgical difficulty, since there was a need for osteotomy and tooth sectioning in the great majority of dental elements due to root dilaceration and divergence, besides the degree of impaction, culminating with greater surgical trauma and, consequently, an increase in postoperative swelling and trismus.

The clinical efficacy of ketoprofen in the control of postoperative pain after extractions of third molars has been widely described in clinical trials $(5,25)$. The use of ketoprofen $75 \mathrm{mg}$ and acetaminophen 1,000 mg was compared, showing lower levels of pain reported by volunteers who received ketoprofen, thus demonstrating that even at lower doses ketoprofen is effective in the control of postoperative pain (25).

Another parameter used to define the postoperative pain intensity of the volunteers in the present study was the amount of rescue analgesic medication (acetaminophen $750 \mathrm{mg}$ ) used which corroborate with many studies evaluating the patient's need to use pain relief medication, thus demonstrating the drug's efficacy in pain modulation $(4,9)$. When volunteers took ketoprofen $100 \mathrm{mg}$ b.i.d., they consumed a greater amount of rescue analgesic medication compared to the use of ketoprofen of $200 \mathrm{mg}+$ omeprazole $20 \mathrm{mg}$ q.d. ( $p=0.0026)$ to reduce postoperative pain. The mean time in hours for the volunteers to take the first tablet of rescue analgesic medication, the results show that when they took ketoprofen $200 \mathrm{mg}+$ omeprazole $20 \mathrm{mg}$ q.d. was $5 \mathrm{~h}$, whereas $7 \mathrm{~h}$ when they used ketoprofen $100 \mathrm{mg}$ b.i.d. $(p=0.53)$. The results differ of Pouchain et al. 2015 (26) compared the effect of nimesulide $100 \mathrm{mg}$ and ketoprofen $100 \mathrm{mg}$, both b.i.d., on the inflammatory parameters related to the surgical removal of third molars, both administered immediately after the surgical procedure, but the use of pain relief drugs was considered unnecessary by volunteer. The data showed that although complete pain relief was not observed, the level of pain was tolerable to volunteers.

In contrast, the administration of several NSAIDs, including ketoprofen, was evaluated in volunteers undergoing surgery for extraction of impacted third molars and it was observed that $75 \%$ of the volunteers consumed pain relief medication during the early onset of pain ( $3 \mathrm{~h}$ after the surgical procedure) and that 24\% of the volunteers consumed pain relief medication immediately after the surgical procedure (27). In the present study, when volunteers took ketoprofen $100 \mathrm{mg}$ b.i.d., used significantly higher total amount of rescue analgesic medication compared to when took ketoprofen $200 \mathrm{mg}+$ omeprazole $20 \mathrm{mg}$ b.i.d. (76 vs. $50 \%$ respectively, $p=0.001$ ).

It is particularly important for the clinician to know which NSAIDs present the highest risk of gastrointestinal complications. In a meta-analysis performed to assess the risk of severe gastrointestinal complications associated with 12 commonly used chronic NSAIDs, ibuprofen represented the lowest risk of gastrointestinal toxicity. In contrast, the relative risk (RR) of some NSAIDs compared with ibuprofen $(R R=1)$ reached values of up to 3.8 (piroxicam) and 4.2 (ketoprofen) (28). Ketoprofen $200 \mathrm{mg}$ drug in combination with omeprazole $20 \mathrm{mg}$ is new on the market and is indicated for the symptomatic treatment of rheumatoid arthritis and osteoarthritis in volunteers at risk of developing ulcer or erosions in the stomach, duodenum or other part of the intestine with the use of NSAIDs. One study evaluated whether the effect of a dose of omeprazole would alter the pharmacokinetics of enteric ketoprofen and determined that omeprazole does not affect hepatic flow rate and is also a more direct agent for the inhibition of gastric acid production, offering advantages for the study of the effect of gastric acidity on the release of enteric coated products (29). The pharmacokinetic profiles of ketoprofen and omeprazole components in this combination used in the present study are comparable to those of the separately administered ketoprofen and omeprazole components. There is no influence on the pharmacokinetics of ketoprofen when administered concomitantly with omeprazole $(13-15,28)$.

Following administration of both study drugs, no adverse reactions were reported by the volunteers. This may be due to the fact that the NSAIDs administered were for a short period of time, and volunteers did not have any underlying disease, blood dyscrasias or drug allergy.

Based on the assumption that other methods for pain assessment contribute to research adopting this type of study model such as in the present study, global assessment is a widely used tool offering a holistic view of drug efficacy in general patient conception $(2,8,9,18)$. Therefore, ketoprofen $200 \mathrm{mg}+$ omeprazole $20 \mathrm{mg}$ b.i.d. shows lower levels of postoperative pain in comparison to ketoprofen $100 \mathrm{mg}$ b.i.d., thus receiving an excellent classification in the global evaluation of the volunteers participating in this study. As described, the combination of ketoprofen $200 \mathrm{mg}+$ omeprazole $20 \mathrm{mg}$ includes a prolonged release form of ketoprofen and a gastroresistant release form of omeprazole, both suitable for once-daily dosing (15). In addition, in comparison with other studies by our study group evaluating different NSAIDs in bilateral third molar extraction model, ketoprofen $200 \mathrm{mg}+$ omeprazole $20 \mathrm{mg}$ b.i.d. showed as good pain control as other drugs evaluated such as piroxicam, valdecoxib, etoricoxib, meloxicam, ketorolac, naproxen $(1,2,8,9,21)$.

In summary, the results of the present study revealed that when volunteers took ketoprofen $200 \mathrm{mg}+$ omeprazole 
$20 \mathrm{mg}$ (q.d.), they reported significantly less postoperative pain at various post-surgical periods and consumed less rescue analgesic medication (acetaminophen $750 \mathrm{mg}$ ) throughout the study compared with ketoprofen 100 mg (b.i.d.). In addition, self-reported global efficacy was significantly more favorable to ketoprofen $200 \mathrm{mg}+$ omeprazole $20 \mathrm{mg}$ (q.d.). As far as swelling and trismus control, both treatments presented similar results.

\section{Resumo}

Em vista dos problemas gastrointestinais gerados pelo uso do cetoprofeno, a associação do cetoprofeno com o omeprazol está disponivel no mercado. No entanto, esta eficácia de associação no controle da dor aguda não foi estabelecida. A extração bilateral de terceiros molares inferiores em posições semelhantes é atualmente o modelo mais utilizado para a avaliação e investigação da eficácia e efeitos farmacológicos de novos compostos para o tratamento da dor aguda pós-operatória. 0 estudo randomizado e cruzado consistiu na avaliação da eficácia clínica da terapia com cetoprofeno $100 \mathrm{mg}$ (duas vezes ao dia-b.i.d.) versus cetoprofeno $200 \mathrm{mg}+$ omeprazol $20 \mathrm{mg}$ (uma vez ao dia-q.d.) para o controle da dor, do edema e do trismo no modelo bilateral de terceiros molares inferiores em posições semelhantes em duas consultas diferentes, em 50 voluntários. Os voluntários relataram significativamente menos dor pós-operatória em vários períodos pós-operatórios e consumiram menos medicação analgésica de socorro (acetaminofeno $750 \mathrm{mg}$ ) durante todo o estudo quando tomaram a combinação de $200 \mathrm{mg}$ de cetoprofeno + $20 \mathrm{mg}$ de omeprazol (q.d.). Após a administração de ambas as drogas do estudo, nenhuma reação adversa gastrointestinal foi relatada pelos voluntários. Além disso, as avaliações das drogas no controle da dor pelos voluntários foram significativamente favoráveis ao cetoprofeno 200 $\mathrm{mg}+$ omeprazol $20 \mathrm{mg}$ (q.d.). Para o controle do edema e do trismo, os tratamentos apresentaram resultados semelhantes. Em conclusão, quando L. os voluntários tomaram $200 \mathrm{mg}$ de cetoprofeno $+20 \mathrm{mg}$ de omeprazol

- (q.d.), eles relataram significativamente menos dor pós-operatória em vários períodos pós-cirúrgicos e consumiram menos medicação analgésica de socorro durante o estudo comparado com $100 \mathrm{mg}$ de cetoprofeno (b.i.d).

\section{Acknowledgements}

Financial support by São Paulo Research Foundation (FAPESP) 2014/25792-0.

\section{References}

1. Calvo AM, Sakai VT, Giglio FP, Modena KC, Colombini BL, Benetello V, et al. Analgesic and anti-inflammatory dose-response relationship of 7.5 and $15 \mathrm{mg}$ meloxicam after lower third molar removal: a double-blind, randomized, crossover study. Int J Oral Maxillof Surg 2007;36:26-31.

2. Trindade $P A$, Giglio FP, Colombini-Ishikiriama BL, Calvo AM, Modena $\mathrm{KC}$, Ribeiro DA, et al. Sublingual ketorolac and sublingual piroxicam are equally effective for postoperative pain, trismus, and swelling management in lower third molar removal. Oral Surg Oral Med Oral Pathol Oral Radiol 2012;114:27-34.

3. Naclério-Homem MG, Deboni MC, Rapoport A. Effects of ketoprofen and diclofenac potassium on blood coagulation tests after removal of third molars. Quintessence Int 2009;40:321-325.

4. Liporaci.Junior JL. Assessment of preemptive analgesia efficacy in surgical extraction of third molars. Rev Bras Anestesiol 2012;62:502510.

5. Hersh EV. The efficacy and safety of ketoprofen in postsurgical dental pain. Compend Educat Dent 1991;12:234-238.

6. McGrath $\mathrm{C}$, Comfort MB, Lo EC, Luo Y. Changes in life quality following third molar surgery-the immediate postoperative period. Br Dent J 2003;194:265-268; discussion 1.

7. Troullos ES, Hargreaves KM, Butler DP, Dionne RA. Comparison of nonsteroidal anti-inflammatory drugs, ibuprofen and flurbiprofen, with methylprednisolone and placebo for acute pain, swelling, and trismus. J Oral Maxillofac Surg 1990;48:945-952.

8. Weckwerth GM, Simoneti LF, Zupelari-Goncalves P, Calvo AM, Brozoski DT, Dionisio TJ, et al. Efficacy of naproxen with or without esomeprazole for pain and inflammation in patients after bilateral third molar extractions: A double blinded crossover study. Med Oral Patol Oral Cirugia Bucal 2017;22:e122-e131.

9. Zupelari-Goncalves P, Weckwerth GM, Calvo AM, Simoneti LF, Dionisio TJ, Brozoski DT, et al. Efficacy of oral diclofenac with or without codeine for pain control after invasive bilateral third molar extractions. I Int J Oral Maxillof Surg 2017;46:621-627.

10. Kaczmarzyk T, Wichlinski J, Stypulkowska J, Zaleska M, Woron J. Preemptive effect of ketoprofen on postoperative pain following third molar surgery. A prospective, randomized, double-blinded clinical trial. J Oral Maxillofac Surg 2010;39:647-652.

11. Orozco-Solis M, Garcia-Avalos $Y$, Pichardo-Ramirez C, Tobias-Azua $\mathrm{F}$, Zapata-Morales JR, Aragon-Martinez $\mathrm{OH}$, et al. Single dose of diclofenac or meloxicam for control of pain, facial swelling, and trismus in oral surgery. Med Oral Patol Oral Cirug Bucal 2016;21:e127-e134.

12. Leone $M$, Richard $O$, Antonini $F$, Rousseau $S$, Chabaane $W$, Guyot $L$, et al. Comparison of methylprednisolone and ketoprofen after multiple third molar extraction: a randomized controlled study. Oral Surg Oral Med Oral Pathol Oral Radiol Endod 2007;103:7-9.

13. Mejia A, Kraft WK. Acid peptic diseases: pharmacological approach to treatment. Expert review of clinical pharmacology 2009;2:295-314.

14. Shin JM, Sachs G. Pharmacology of Proton Pump Inhibitors. Current Gastroent Reports 2008;10:528-534.

15. Palmieri GF, Bonacucina G, Di Martino P, Martelli S. Gastro-resistant microspheres containing ketoprofen. Journal Microencapsulation 2002;19:111-119.

16. Garcia AG, Sampedro FG, Rey JG, Vila PG, Martin MS. Pell-Gregory classification is unreliable as a predictor of difficulty in extracting impacted lower third molars. Br J Oral Maxillofac Surg 2000;38:585587.

17. Santos $C F$, Modena KC, Giglio FP, Sakai VT, Calvo AM, Colombini BL, et al. Epinephrine concentration $(1: 100,000$ or $1: 200,000)$ does not affect the clinical efficacy of $4 \%$ articaine for lower third molar removal: a double-blind, randomized, crossover study. J Oral Maxillofac Surg 2007;65:2445-2452.

18. Senes AM, Calvo AM, Colombini-Ishikiriama BL, Goncalves PZ, Dionisio TJ, Sant'ana E, et al. Efficacy and Safety of 2\% and 4\% Articaine for Lower Third Molar Surgery. J Dent Res 2015;94:166s-173s.

19. Colombini BL, Modena KC, Calvo AM, Sakai VT, Giglio FP, Dionisio TJ, et al. Articaine and mepivacaine efficacy in postoperative analgesia for lower third molar removal: a double-blind, randomized, crossover study. Oral Surg Oral Med Oral Pathol Oral Radiol Endod 2006;102:169174.

20. Gregorio LV, Giglio FP, Sakai VT, Modena KC, Colombini BL, Calvo AM, et al. A comparison of the clinical anesthetic efficacy of $4 \%$ articaine and $0.5 \%$ bupivacaine (both with 1:200,000 epinephrine) for lower third molar removal. Oral Surg Oral Med Oral Pathol Oral Radiol Endod 2008;106:19-28.

21. Calvo AM, Zupelari-Goncalves P, Dionisio TJ, Brozoski DT, Faria FA, Santos CF. Efficacy of piroxicam for postoperative pain after lower third molar surgery associated with CYP2C $8^{*} 3$ and CYP2C9. J Pain Res 2017;10:1581-1589.

22. Calvo AM, Brozoski DT, Giglio FP, Goncalves PZ, Sant'ana E, Dionisio TJ, et al. Are antibiotics necessary after lower third molar removal? Oral Surg Oral Med Oral Pathol Oral Radiol 2012;114:S199-S208.

23. Hawker GA, Mian S, Kendzerska T, French M. Measures of adult pain: Visual Analog Scale for Pain (VAS Pain), Numeric Rating Scale for Pain (NRS Pain), McGill Pain Questionnaire (MPQ), Short-Form McGill Pain Questionnaire (SF-MPQ), Chronic Pain Grade Scale (CPGS), Short Form-36 Bodily Pain Scale (SF-36 BPS), and Measure of Intermittent and Constant Osteoarthritis Pain (ICOAP). Arthritis Care Res 2011;63 Suppl 11:S240-S252.

24. Jensen MP, Martin SA, Cheung R. The meaning of pain relief in a clinical trial. J Pain 2005:6:400-6. 
25. Bjornsson GA, Haanaes HR, Skoglund LA. Ketoprofen $75 \mathrm{mg}$ qid versus acetaminophen $1000 \mathrm{mg}$ qid for 3 days on swelling, pain, and other postoperative events after third-molar surgery. J Clin Pharmacol 2003;43:305-314.

26. Pouchain EC, Costa FW, Bezerra TP, Soares EC. Comparative efficacy of nimesulide and ketoprofen on inflammatory events in third molar surgery: a split-mouth, prospective, randomized, double-blind study. Int J Oral Maxillof Surg 2015;44:876-884.

27. Levrini L, Carraro M, Rizzo S, Salgarello S, Bertelli E, Pelliccioni GA, et al. Prescriptions of NSAIDs to patients undergoing third molar surgery: an observational, prospective, multicentre survey. Clin Drug Investig 2008;28:657-668.
28. Henry D, Lim LL, Garcia Rodriguez LA, Perez Gutthann S, Carson JL, Griffin $M$, et al. Variability in risk of gastrointestinal complications with individual non-steroidal anti-inflammatory drugs: results of a collaborative meta-analysis. BMJ (Clin Res) 1996;312:1563-1566.

29. Andersson T. Omeprazole Drug Interaction Studies. Clin Pharmacokinet 1991;40:195-212.

Received January 11, 2018

Accepted March 18, 2018 